\title{
Reviewing and Evaluating the Direct Elections to the Legislative Council and the Transformation of Political Parties in Hong Kong, 1991-2016
}

\author{
Chung Fun Steven Hung \\ The Education University of Hong Kong, Hong Kong
}

\begin{abstract}
After direct elections were instituted in Hong Kong, politicization inevitably followed democratization. This paper intends to evaluate how political parties' politics happened in Hong Kong's recent history. The research was conducted through historical comparative analysis, with the context of Hong Kong during the sovereignty transition and the interim period of democratization being crucial. For the implementation of "one country, two systems", political democratization was hindered and distinct political scenarios of Hong Kong's transformation were made. The democratic forces had no alternative but to seek more radicalized politics, which caused a decisive fragmentation of the local political parties where the establishment camp was inevitable and the democratic blocs were split into many more small groups individually. It is harmful. It is not conducive to unity and for the common interests of the publics. This paper explores and evaluates the political history of Hong Kong and the ways in which the limited democratization hinders the progress of Hong Kong's transformation.
\end{abstract}

Keywords: election politics, historical comparative, ruling, democratization

The democratizing element of the Hong Kong political system was bounded within the Legislative Council under the principle of the separation of powers of the three governing branches, Executive, Legislative, and Judicial. Popular elections for the Hong Kong legislature were introduced and implemented for 25 years (1991-2016) and there were eight terms of general elections for the Legislative Council. This review is necessary in order to understand and analyze the situation we are faced with and the transformation that is actually being carried out.

Only $30 \%$ of the legislative councillors were directly elected in 1991 and were determined by the Basic Law with $50 \%$ of the legislative councillors directly elected in 2004, which indicates that the organization of the Legislative Council does not democratize further. However, the introduction of directly elected members to the Legislative Council made the political spectrum change significantly. This paper is going to review the political situation in Hong Kong as this direct election mechanism was introduced into the society of Hong Kong. The explanation of this historical context can enrich our understanding of Hong Kong before and after the political transition in 1997, over a period of 25 years.

Corresponding author: Chung Fun Steven Hung, Ph.D. in Business Administration, Department of Social Sciences, The Education University of Hong Kong, Hong Kong; research fields: Hong Kong politics, student movement, and civic education policy. 


\section{Concept of Study: The Political History of Hong Kong}

The Government of the United Kingdom and the Government of People's Republic of China reviewed the existing relationship between the two Governments in the early 1980s. They came to an agreement that the sovereignty of Hong Kong would be transferred from the United Kingdom to the People's Republic of China. The Sino-British Joint Declaration, which was signed in December 1984, stated that the basic policies regarding Hong Kong for China would be upholding national unity and territorial integrity. After 1997, Hong Kong would be under the sovereignty and authority of the Central Government and would enjoy a high degree of autonomy under China's domination. Arrangements for the transition to Chinese rule were subject to the supervision of the Sino-British Joint Liaison Group, formed by representatives of Britain and China respectively. Representatives from Hong Kong were excluded from negotiating concerning their future.

After the suppression of the student-led democratic movement in Tiananmen Square in 1989, the British Government announced that measures would be taken to restore the confidence of the people of Hong Kong. The Basic Law was drafted and formally promulgated on April 4, 1990. The political system it stated should be formed through elections. It confirmed that the selection of Chief Executive and members of the legislature should ultimately be done through means of universal suffrage. Consequently, democratic reforms were introduced in 1991 at an accelerated pace. At last, the path of democratization for the Legislative Council was confirmed before 2007 (see Table 1).

Table 1

Numbers and Percentages of Directly Elected Seats to the Legislative Council by Year

\begin{tabular}{llll}
\hline Year & Number of seats & Directly elected & Percentage \\
\hline 1991 & 60 & 18 & $30 \%$ \\
1995 & 60 & 20 & $33.3 \%$ \\
1998 & 60 & 20 & $33.3 \%$ \\
2000 & 60 & 24 & $40 \%$ \\
2004 & 60 & 30 & $50 \%$ \\
2008 & 60 & 30 & $50 \%$ \\
2012 & 70 & $35(+5)$ & $50 \%(57 \%)$ \\
2016 & 70 & $35(+5)$ & $50 \%(57 \%)$ \\
2020 & 70 & $35(+5)$ & $50 \%(57 \%)$ \\
\hline
\end{tabular}

In contrast, functional constituencies, which were not democratic and maintained in the political system of Hong Kong, were found in very few system of government (Miners, 1998, p. 116) internationally. However, only directly elected members of Hong Kong's parliamentary system can rightly represent democracy but it was adopted late, not until 1991. These reforms were implemented six years before the transfer of sovereignty, such that, critically speaking, the people of Hong Kong should not have had enough practice of implementing these semi-democratic operations of the governing system before the transition of the power of sovereignty.

The ratio of directly elected members of the Legislative Council represented the extent of democratization of Hong Kong's political system. However, the progress was obviously too slow, which could suit Hong Kong's democratization and fair and equal social policy. The pace of democratization was further hindered by the decision of the Standing Committee of the National People's Congress in 2004. After the massive protests against the security law legislation in July 2003, when more than 500,000 people took to the streets, China said 
that they would not implement the expected universal suffrage in 2007. In light of this constraint, the package of faked political reforms was vetoed by the Legislative Council in December 2005.

With the pressure being mounted by the democratic bloc concerning universal suffrage, the establishment camp stated its preference for 2017. The Standing Committee resolved on December 29, 2007 that the election of the Chief Executive in 2017 may be done by universal suffrage. The direct election of all members of the Legislative Council may also be implemented on the condition that the Chief Executive is selected by universal suffrage, and hopefully, the universal suffrage of the Legislative Council will be implemented in 2020.

The government issued "the Consultant Document on the Methods for Selecting the Chief Executive and for Forming the Legislative Council in 2012" on November 18, 2009. This proposal was not democratizing enough, but suggested enlarging the "small circle" Election Committee from 800 members to 1,200 members. The members of the Legislative Council could be increased to 70, but these were restricted through a 50-to-50 ratio. After the "Five Constituencies Resignation Referendum" campaign, the democratic blocs were separated into moderate democrats and radical democrats. The Democratic Party counter-proposed and amended the government reform package. The new reform package was passed by adding five seats from geographical constituencies and five seats from all voters, except those with voting rights in other functional constituencies. But this set a bad example of limiting and controlling nomination procedures (see Table 1).

China set limits with respect to the Chief Executive election, while notionally allowing for universal suffrage. As the method proposed for selecting the Chief Executive by universal suffrage must provide institutional safeguards for the nomination, a nominating committee would be made up of 1,200 members, which was to nominate only two to three candidates, each of who must have the support of more than half of the members of the nominating committee. After the popular election, the Chief Executive election would have to be approved by the Chinese Government. Demonstrations started outside the Government Headquarters. It triggered a shift towards an occupy movement type of outcome and the atmosphere of Hong Kong politics was progressively radicalized. The government's reform proposal failed, as eight legislators dramatically voted in favour on June 18, 2015 and 28 voted against, barely meeting the quorum of 35. The democratization process in Hong Kong became deadlocked. The people of Hong Kong did not accept the decision of the Standing Committee and the faked universal suffrage for electing the Chief Executive could not be implemented. This meant that the democratization of the electoral mechanism was unable to make any progress. And this political background of Hong Kong's history can provide details for interpreting the transformation of political parties in Hong Kong.

The functions and roles of the Legislative Council are to enact, amend, or repeal laws and they can examine and approve the official budgets, taxation, and public expenditures of the Hong Kong Government and raise questions concerning the work of the government. However, these roles and functions of passing legislation, approving government appropriation and expenditures, and monitoring public polices and representation have changed and developed with Hong Kong's historic and constitutional transformation (Ng, 2014, p. 106).

The Legislative Council plays roles in the context of Hong Kong's political situation and it represents different political forces within it $(\mathrm{Ng}, 2014$, p. 106). The transfer of the sovereignty of Hong Kong was a prominent event. If political parties are institutions that bring together people for the purpose of exercising power through the state, this cannot apply in Hong Kong. Hong Kong does not have governing political parties, as the constitutional framework does not favour the formation of a ruling party. The conservative stances of the Councillors can be considered on a spectrum of how pro-government they are, which is more or less 
synonymous with being pro-Beijing ( $\mathrm{Ng}, 2014$, p. 106). Nowadays, the term has been tactically defined as the establishment camp, but what the term used to be called was the conservative royalists. The Legislative Council could not be a rubber stamp body but the majority of them had no alternative, as they were compelled by these circumstances and pushed into supporting the government's policies.

If political parties seek to use legitimate means for pursuing their ends, the opposition camp was democratic since the Communist Central Government has been reluctant to allow Hong Kong to have sufficient democracy. They are the members who have actively pursued democracy. The opposition insists that their vital objective is to counteract the central policies that aim to exercise more control over the freedom and human rights of the people of Hong Kong.

Recently, they are called the pan-democrats. We should remember that "pan" is a prefix which means general, but the speaking sound in Cantonese is "fan", which means criminal. This nickname can easily be translated as guilty people. Or the most recent, they are further onwards called the non-establishment camp. They are understood as only destructive, not as people who work to establish something. A political party whose reputation is marked by political stigma should critically be avoided, but we cannot decide what should be right term to address the various political parties and different camps. And the stigmatization of political parties in Hong Kong was remindful and noticeable.

As a matter of fact, being the representatives for the people of Hong Kong and not only the legal profession, the uppermost concern of the democratic bloc was the safe transition of the rule of law and the protection of the rights and liberties of the people of Hong Kong ( $\mathrm{Ng}, 2014$, p. 107). On the other hand, the Basic Law established different structures institutionally, in terms of the separation of powers within the new constituted Hong Kong in 1997 (Ng, 2014, p. 106). That is to say, the constituents and voting procedures within the Legislative Councils favoured divergence rather than consensus (Ng, 2014, p. 106).

The fight for democracy for the people of Hong Kong inevitably signifies the vital role of the democratic bloc. Under the constraints of the Basic Law and 10 years after the transfer of sovereignty in 2007, the new process of democratization would be implemented and the Hong Kong Government would not have any pre-defined interests by the planning of implementation of political reform by public consultation. However, democracy does not drop from the sky. The conservative and the pro-government camps would like to postpone the timetable for implementing universal suffrage.

Hong Kong's political arena does not only orchestrate different political forces, but also advocates new and creative political stances in relation to the political transformation. With several attempts at political reforms hindered by the Communist Central Government and the real promise of democratization having come to nothing in Hong Kong, the democratic localization, self-determination, and independence movement come to be future agenda for different fates of Hong Kong. With respect to the civil unrest that occurred in Mong Kok on February 8, 2016, political parties that started out as civil organizations can become engaged in open and armed conflict with the regime in Hong Kong, either because it has decided to resort to the use of force or because the regime has chosen to repress it. If those political struggles mediated by the institutional setting are right, democratization is the only one way to solve the problem of local continuous conflicts in Hong Kong.

\section{Historical Comparative Analysis as Methodology}

The political sociological research is comparative since social events are often typical and unique. The historical comparative research stems from the incomplete nature of historical data, the complexity and scale of 
the social systems, and the nature of the questions asked. In order to investigate and evaluate the elections of the Hong Kong legislature, as a matter of fact, the historical data are not a difficult set of data to work with. They are the historical evidence that election results provide, whether political parties gained support or not. However, the real problems are the complexity of social and political systems in Hong Kong, being generated and regenerated through the history. The research had to deal with many personal affairs and classify their political attributes, which is a great task. The processes of democratization are locked into the related historical context of Hong Kong. The paper covers a broad and wide-ranging topic in comparative research concerning how democracy evolved and what political forces and political parties transformed this region.

\section{The Legislative Council Elections Before the Handover}

The implementation of direct elections to the Legislative Council was started in 1991 after the negotiations between China and Britain. Owing to the June Fourth Event in 1989, the path of democratization was changed and the predetermined arrangement of providing 10 seats for direct election in 1991 was increased to 18 seats. It was then increased gradually and very slowly from $30 \%$ of seats in 1991 to $50 \%$ in 2004 , as planned by the Basic Law. The following sections give a detailed explanation and analysis of the elections outcomes and an evaluation of the transformation of the political context.

The 1991 general election. The British Hong Kong Government was well prepared for the first direct election of 10 member seats to the Legislative Council in 1991. Owing to the democratic movement in Hong Kong, which had been mobilized by Beijing's student-led democratic movement in 1989, the pace for democratization was accelerated with 18 seats being directly elected and the political organizations of Hong Kong being reintegrated. The three main democratic organizations - the Association for Democracy and People's Livelihood (ADPL), the Meeting Point (MP), and the Hong Kong Affairs Society (HKAS) - were reintegrated in order to establish the Hong Kong United Democrats (UD) with other independent democratic societies and individuals. Martin Lee and Szeto Wah, as the famous democratic fighters and drafters of the Basic Law, led the first political party of Hong Kong and signified that it intended to fight for Hong Kong's democracy. It became the biggest democratic force in Hong Kong. Some members of ADPL kept themselves in ADPL and remained a second force of the democratic group. Members of MP joined with UD and united to become allies in contesting the election in 1991.

However, there were only 18 members directly elected and divided into nine geographical constituencies by a "one man two votes" system with another 21 members elected from functional constituencies. Moreover, there were another 17 members who were appointed by the Hong Kong Governor and three official members. Furthermore, owing to the preparations for the transfer of sovereignty of Hong Kong in 1997, it was the first time the constituents of the Legislative Council contained more than $50 \%$ elected members. In the direct election, there were nine constituencies and voters could select not more than two candidates to be legislators. The two-seat constituency vote system was adopted with two seats to be filled in each constituency. However, this voting system made it possible for the pro-democratic allies to win in a landslide, getting 16 out of the 18 geographical constituency seats as a result of election. In this first direct election in Hong Kong, the UD dominated and gained 14 out of the 18 seats. The ADPL contested three seats but won only one and Emily Lau was the only one independent democrat who was able to gain a seat and become a legislative councillor. Andrew Wong was a university lecturer, with a relatively open democratic and to some extent conservative background of the Rural Committee, who was able to win the election. Tai Chin-wah was the only conservative 
and pro-Beijing representative who won a seat in the election. However, due to his falsified qualification of practicing solicitor member, he committed a crime, resigned, and was given a six-month criminal jail sentence. The election showed the discontent with the pro-Beijing participants, having contested a total of 11 seats and only being able to win one; the democratic bloc dominated the election, receiving $65 \%$ of the votes and winning 16 out of 18 seats. Moreover, the Hong Kong UD dominated the election and won the most seats from the direct elections and the other democratic blocs were only able to gain marginal seats (see Table 2) as a result.

Table 2

The Results of Legislative Council's Direct Elections Under British Governance

\begin{tabular}{lllllll}
\hline \multicolumn{3}{c}{$1991(18$ seats $)$} & \multicolumn{1}{c}{$1995(20$ seats) } \\
\hline $\begin{array}{l}\text { Political } \\
\text { blocs }\end{array}$ & $\begin{array}{l}\text { Votes } \\
\text { gained }\end{array}$ & \% of votes & $\begin{array}{l}\text { Seats won } \\
\text { (candidates) }\end{array}$ & $\begin{array}{l}\text { Votes } \\
\text { gained }\end{array}$ & \% of votes & $\begin{array}{l}\text { Seats won } \\
\text { (candidates) }\end{array}$ \\
\hline DP & 716,797 & 52.35 & $14(17)$ & 385,428 & 42.26 & $12(14)$ \\
ADPL & 60,770 & 4.44 & $1(3)$ & 87,072 & 9.55 & $2(5)$ \\
Others & 111,160 & 8.12 & $1(4)$ & 85,020 & 9.32 & $2(4)$ \\
Democrats & 888,727 & 64.91 & $16(24)$ & 581,181 & 61.13 & $16(23)$ \\
DAB & 91,017 & 6.64 & $0(3)$ & 142,801 & 15.66 & $2(7)$ \\
LP & & & & 15,126 & 1.64 & $1(1)$ \\
Others & 145,116 & 10.60 & $1(8)$ & 120,923 & 13.28 & $0(12)$ \\
Pro-Beijing & 236,133 & 17.24 & $1(11)$ & 278,850 & 30.58 & $3(20)$ \\
Independent & 244,453 & 17.85 & $1(19)$ & 72,992 & 5.41 & $1(15)$ \\
\hline
\end{tabular}

Notes: The Democratic Party (DP) was established in 1994, before it, there were two separate political parties, the Hong Kong United Democrats (UD) and the Meeting Point (MP). The Liberal Party (LP) was formed in 1993 and derived from the Co-operative Resources Centre; it was founded by a group of conservative politicians appointed or elected through the business functional constituencies. The major pro-Beijing candidates were the members of the Hong Kong Progressive Alliance, but they were influential and not all members shared their membership in elections.

The 1995 general election. Before the second direct election, the UD and the MP merged into the Democratic Party (DP) in 1994, but they refused to let ADPL join. The pro-business legislators of Co-operative Resources Centre reorganized and established the Liberal Party (LP). And the pro-Communist government politicians established the Democratic Alliance for the Betterment of Hong Kong (DAB).

The second direct election to return members to the Legislative Council was held in 1995, which was the last election held under the British decolonizing project before the handover of sovereignty, and it was the first fully elected legislative election with one-third of the seats (20) being directly elected. In order to prevent the democratic bloc from monopolizing the seats through a landslide victory by virtue of the two seats constituency system, the election mechanism was replaced by the "one man one vote" principle and 20 geographical constituencies were organized. The winner of each constituency would be the one that got the most votes in the single district. However, the newly formed DP was the biggest political bloc. They had 14 members taking part in the direct elections and 12 won. The other democratic groups were able to win four seats through direct election. The most important competition was the Kowloon East District, where Szeto Wah competed with Elsie Tu. Elsie Tu was formerly democratic, but had suddenly become conservative. She was defeated and the competition showed that the newly formed democratic forces were gaining more support in its effort to replace the traditional one. Even the conservative force was largely central in coordinating their candidates and all coalesced into a united front against the democrats (Ma \& Choy, 2003, p. 637); they won only three seats from 
direct election but their share of votes increased dramatically from $17.24 \%$ in 1991 to $30.58 \%$ in 1995 . The 1995 election was still beneficial to the more popular democrats.

In the election, DP successfully managed to avoid a conflict with other prominent and friendly pro-democracy candidates, like Emily Lau, Christine Loh, and Frederick Fung (Ma \& Choy, 2003, p. 637). Generally speaking, the pro-democracy forces won a landslide victory again, winning 16 of the directly elected seats. As the Electoral College was formed by all the directly elected members of the 18 District Boards, and the newly formed nine functional constituencies were created by around 2.7 million workers, the democratic camp gained marginally half of the total seats in the legislature. This situation allowed the independent and directly elected Andrew Wong to become the President of the Legislative Council. At this stage, the Frontier, ADPL, LP, and DAB were only mini-political groups that were able to win one or two seats through direct election. Although the last tango was danced, the pro-democracy legislature could last a mere 21 months and was replaced by Beijing when it established the Provisional Legislative Council on July 1, 1997. The Communist Chinese Government made the Hong Kong political system more authoritarian and undermined the democratic progress that had been made.

\section{The Legislative Council Elections After the Handover}

The sovereignty of Hong Kong was transferred from Great Britain to the People's Republic of China on July 1, 1997. Hong Kong became the Special Administrative Region of the People's Republic China and China promised to rule Hong Kong according to the "one country, two systems" formula. Except with respect to foreign affairs and national defence, Hong Kong was to have a high degree of autonomy in all matters.

The politics of Hong Kong were transformed under the framework of the political system constructed and dominated by the Hong Kong Basic Law. As a matter of fact, democratization was limited and bound within the constraints of the Basic Law. There were six elections to the Legislative Council from 1998 to 2016. The results of the elections are obviously indicative of the change and transformation of politics in Hong Kong, and the following sections continue to explain these.

The 1998 general election. After 1997, the sovereignty of Hong Kong was transferred to the People's Republic of China and the legislature was replaced by the Beijing-controlled Provisional Legislative Council. The first election was held in May 1998. The elections elected 20 members from directly elected regional constituencies. The undemocratic ways of electing members meant that 30 seats came from functional constituencies and 10 seats came from the Electoral College. The electoral mechanism of geographical constituencies for the first time adopted the system of party-list proportional representation in 1998, with seats allocated by the largest remainder method using the Hare quota as the quota for election. However, it was predicted that the election would change from a being a polarized competition to a more diversified or pluralistic one (Ma \& Choy, 2003, p. 634).

The mechanism was precisely designed and installed by the Chinese Government and so the DAB was guaranteed and recorded a clear increase in the number of seats it gained in the election. They acquired five seats as a result of this direct election in 1998, having obtained only two seats in the 1995 election. But actually, they gained votes, having received 142,801 votes (15.66\%) in 1995, and they received 373,428 votes (25.2\%) in 1998. The main reason behind the increased number of votes they obtained was that they participated in all the direct electing constituencies, as they ran elections for merely seven districts out of 20 (35\% area) in 1995 . On the other hand, the DP acquired 385,428 (42.26\%) votes in 1995 and increased the number of votes they 
received dramatically to $634,635(42.9 \%)$ in 1998 . As a result, the election resulted in the DP dropping seats, going from 12 seats in 1995 to nine seats in 1998, and DAB increasing its share of seats, going from two seats in 1995 to five seats in 1998. However, the voting rate reached a record high of $53.29 \%$. The competition slogan of the democratic bloc was quite successful in 1998, where it was led by the DP, saying, "returning to the parliament requires people". Fredrick Fung, representing the ADPL, as a democrat, was punished due to having participated in the Provisional Legislative Council and lost his seat in the election. The Frontier led by Emily Lau participated in merely in two geographical constituencies out of five, was able to illustriously acquire 148,507 (10.0\%) votes and three seats in the election. Basically, the democrats acquired $66.2 \%$ of the votes and won 15 seats, with voters sympathizing with how they had refused to join in the Provisional Legislative Council.

The LP participated in four geographical constituencies, and only gained 50,335 (3.4\%) votes, suffered defeat totally, and obtained no seat in the direct elections. But they still emerged as the second biggest party, as they won 10 seats through the undemocratic functional constituency elections. The results of the 1998 election showed that the democratic blocs had once again collectively gained two-thirds (979,199 votes) of the popular vote. Due to the new electoral counting system, their share of directly elected seats shrank from 16 seats $(80 \%)$ to 15 seats $(70 \%)$. The DP was still the biggest democratic group, allied with mini-democratic groups, being the opposition camp. Among the establishment camp, only DAB could survive in the direct election and started to be fully fledged for the elections. In fact, DAB had another membership for the election, in that they represented the Hong Kong Federation of Trade Unions (FTU), which was the greatest trade union with more than 300,000 members at that time. On the other hand, the chairman of the LP was Allen Lee, who was a very dignitary person but who was defeated in the election. Before participating in the elections, he was the Senior Unofficial Member of the legislature and the Unofficial Member of the Executive Council of Hong Kong. It was to tell that the establishment camp was monopolized by DAB only and the other mini-conservative groups lost their elections.

The 2000 general election. Two years later, there was another election with the economic situation still not having returned to normal after the Asian economic meltdown in 1997. The 2000 legislative election returned 24 members from the directly elected geographical constituencies. The biggest party, the DP, adopted splitting teams in order to acquire more seats. They had two teams in the New Territories East District and three teams in the New Territories West. They managed to win two seats separately in these two districts. In total, the DP was merely able to maintain nine seats, as one member, Lau Chin-shek, transferred his membership to the Frontier. However, the democratic blocs lost almost 200,000 votes as the turnout rate decreased from $53.3 \%$ in 1998 to $43.6 \%$ in 2000 .

But DAB did not see its support decrease on such low voting turnout rate. The remarkable district was the Kowloon East where the DP and DAB got two seats each. But the team led by Chan Yuen-han received 108,587 votes, compared to the team led by Szeto Wah that received 103,863 votes. It signified that DAB's pro-Communist team received more votes than the Democratic Party for the first time. Szeto was famous, as he was actually the Hong Kong father of Chinese Nationalism and was eminent in leading the organization of the Hong Kong alliance in Support of Patriotic Democratic Movements in China, but he could not win the election. On the other hand, the scandal with respect to DAB was Gary Cheng's corruption case. He declared that he would resign after the election, and hence, this was not harmful for the election and did not too much affect the election results, winning two seats in the Hong Kong Island District. His seat was vacated later and Audrey Eu 
won it in the Hong Kong by-election in 2000. LP totally lost in the district direct election and did not gain any seats again, but they were still the second largest political party as they won nine seats in the functional constituencies.

Even with the seats that were directly elected having been increased from 20 to 24, DP could not acquire more seats, as it could be seen that their support had started to deteriorate. The switch of the election mechanism to the proportional representation system contributed to a rise in the DP's factionalism (Ma, 2007b, p. 145). Different candidates struggled over the party nominations and the decision to split party lists (Ma, 2007b, p. 145). They received 634,635 votes in 1998 but only 417,873 votes in 2000, losing a dramatic 50\% of their votes. Fredrick Fung was re-elected to his seat as a representative of ADPL. Andrew Wong, formerly the Chairman of the Legislative Council, was the only independent who was able to secure their seat. The radicalist, Leung Kwok-hung (Longhair), participated for the first time in the Hong Kong election. He got 18,235 votes, insufficient to win a seat, but emerged with an improved reputation, laying the groundwork for his coming success in subsequent elections.

The 2004 general election. The second term of Tung's Chief Executive Administration started in July 2002 and he intended to strengthen Hong Kong's social control. The Special Administrative Region's government released the proposal for the anti-subversion law. It caused considerable controversy and division in Hong Kong. Protests against the bill resulted in a massive demonstration on July 1, 2003 and triggered the continuous and unceasing democratization movement in Hong Kong. The public outrage against the bill was gradually transformed into an urge for the Chinese Government to introduce universal suffrage. Moreover, after Audrey Eu won a seat as a legislator - she was formerly the Chairlady of the Hong Kong Bar Association - she became the founding member of the Basic Law Article 23 Concern Group, which was later transformed into the Basic Law Article 45 Concern Group, which also had some other notable members of the Bar, including Alan Leong and Ronny Tong. Later, they participated in the Legislative Council election in 2004 and won three seats.

However, the election result in Hong Kong Island was the most dramatic. Eu ran in the 2004 Legislative Council election on the same ballot as Cyd Ho. The team obtained 73,844 votes $(16.67 \%+4.19 \%)$, which resulted in Eu acquiring a seat at the expense of Ho, who lost out to her nearest DAB rival Choy So Yuk $(74,659$ votes, $16.67 \%+4.42 \%)$ by a mere 815 votes. This was seen as a blunder by the democrats, as the team of Martin Lee and Yeung Sum had more than enough votes (131,788 votes, $16.67 \%+16.67 \%+4.19 \%)$ to win, mistakenly affecting Cyd Ho's election chances. If the democratic blocs could balance the votes rightly, the situation would guarantee them four seats in Hong Kong Island. The result was that they only gained three seats, evenly shared with the conservative camp, but having received a total vote share of $59.2 \%$.

This 2004 election was conducted under "the 1 July effect", which was the protest with more than 500,000 marchers and the number of directly elected seats was increased to 30 , half of the members being directly elected for the first time. The voting rate reached an all time historical high at 55.64\% and saw 1,784,406 persons cast ballots, the highest ever percentage of voting, and the greatest number of voters (comparing with 1998, 53.29\% and 1,489,705 votes, see Table 5).

The direct election results in the geographical constituencies showed two camps, obviously established camp through their stable supporters after the massive social movement. The establishment camp did not expect to be defeated by the massive political movement and started to stabilize the $40 \%$ of votes they obtained. The LP acted as a key agent in standing up against the subversion law legislation and this made them heroes. They gained their highest number of votes (two seats, 118,997 votes, and 6.7\%) historically, acquired 10 seats in total, 
and maintained their position as the second biggest party in Hong Kong. It was understandable that the pro-Beijing camp advanced gradually and entrenched themselves carefully at every step in the election. A defensive approach to the election was adopted by the establishment camp, preventing from being overly attacked by the democrats.

Starting from the beginning, the democratic bloc coordinated the elections strategically. The major democratic candidates comprised five separate lists and they finally won six seats out of the eight seats in the New Territories West. The other case was in the New Territories East constituency. Leung Kwok-hung and Andrew Wong were not included in the coordination and the democrats finally agreed to run as a single list and to make it as a "diamond list" in order to get four seats in the election in the region. The final results of the election showed that the share votes obtained by this list was $39 \%$, even lower than the total vote share of the DP plus the Frontier in the 2000 election (44\%). Moreover, the Left radicialist, Leung Kwok-hung, was elected and the democratic middleman, Andrew Wong, was defeated, which indicated that there was no room for politicians taking the third way in Hong Kong. But it was the first time that the Left radicalist, Leung Kwok-hung (Longhair), was elected and he challenged the monopolized regime quite seriously in Hong Kong. His victory also signified the radicalization of Hong Kong politics.

The 2008 general election. The 2008 Hong Kong Legislative Council election was held on September 7, 2008, following Donald Tsang's re-election as the Chief Executive in 2007. As the Standing Committee of the National People's Congress made the decision to allow universal suffrage in the election to the Chief Executive by 2017 and the full Legislative Council election by 2020, it tempered the debate on the issue of democratization by universal suffrage. The political atmosphere was relatively settled down and the election looked like that it would be void of focus. The Legislative Council was still keeping the system that saw 30 members elected by geographical constituencies through direct election and another 30 members by functional constituencies, but it kept the historical highest rate that 14 functional constituency seats were not contested by the opposition. Commentators noted that the fighting among the pro-democratic parties was heating up as the proportional representation as a mechanism was built in protection for the multi-party competition in Hong Kong. However, Hong Kong citizens witnessed a noisy, disputed, and disordered election forum that made a bad impression that the competitors were not fighting to protect people's rights but only fought for their own interests. This atmosphere made voters lose interest and dispel their mood to vote. The number of votes dropped from 1,784,406 (55.64\%) in 2004 to $1,524,249$ (45.20\%) in 2008.

The Civic Party (CP) was established in 2006, which is a liberal and pro-democracy party that was derived from the Basic Law Article 45 Concern Group. The CP could not gain success in the election, due to the failed runs for election by Fernando Cheung in the New Territories West geographic constituency and Claudia Mo in the Kowloon West geographic constituency. The electoral performance led the party to conclude that it needed to rectify its weakness at the grassroots level.

The other democratic political group that was founded in 2006 was the League of Social Democrats (LSD) by two Legislative Councillors, Leung Kwok-hung and Albert Chan. It positioned itself as a grassroots clear-cut opposition party. They won three seats in the election by gaining over $10 \%$ of the vote (153,390 votes) and emerged as the sixth largest political party in Hong Kong, seemingly the new democratic and radical power in Hong Kong society.

That two parties had been founded and were participating in the elections signified that the multi-party system was secured and the splitting of democratic bloc occurred as the LSD fiercely criticized the other two 
democratic parties during the election campaign, the DP and the $\mathrm{CP}$, for inappropriately participating in the "small circle" Chief Executive election in 2005 and 2007 respectively.

The leading role of the DP was challenged, as they gained 312,692 (20.6\%) votes, which was surpassed by the DAB (347,373 votes, 22.9\%) even if they gained the same seven seats in the direct elections (see Table 3). Obviously, their support was shared by the other similar democratic blocs. On the other hand, the establishment camp separated their teams strategically and tactically as well in order to acquire more seats.

Table 3

The Direct Election Results of the Legco, Seats Gained (\% Shares \& Votes)

\begin{tabular}{|c|c|c|c|c|c|c|}
\hline Yea & $\begin{array}{l}1998 \\
(20 \text { seats })\end{array}$ & $\begin{array}{l}2000 \\
(24 \text { seats })\end{array}$ & $\begin{array}{l}2004 \\
(30 \text { seats })\end{array}$ & $\begin{array}{l}2008 \\
(30 \text { seats })\end{array}$ & $\begin{array}{l}2012 \\
(35 \text { seats })\end{array}$ & $\begin{array}{l}2016 \\
(35 \text { seats })\end{array}$ \\
\hline \multirow{2}{*}{ DAB } & $5(25.2 \%)$ & $7(28.4 \%)$ & $8(22.7 \%)$ & $7(22.9 \%)$ & $9(20.2 \%)$ & $7(16.68 \%)$ \\
\hline & 373,428 & 374,780 & 402,420 & 347,373 & 366,140 & 361,617 \\
\hline \multirow{2}{*}{ FTU } & & & $1(3.0 \%)$ & $2(5.7 \%)$ & $3(7.1 \%)$ & $3(7.83 \%)$ \\
\hline & & & 52,565 & 86,311 & 127,857 & 169,854 \\
\hline \multirow{2}{*}{ New People's Party } & & & & $1(4.1 \%)$ & $2(3.8 \%)$ & $3(7.58 \%)$ \\
\hline & & & & 61,073 & 68,097 & 166,899 \\
\hline \multirow{2}{*}{ Liberal Party } & $0(3.4 \%)$ & $0(1.9 \%)$ & $2(6.7 \%)$ & $0(4.3 \%)$ & $1(2.7 \%)$ & $0(3.04 \%)$ \\
\hline & 50,335 & 24,858 & 118,997 & 65,622 & 48,702 & 66,984 \\
\hline \multirow{2}{*}{ Establishment individuals } & & $1(2.0 \%)$ & $1(4.9 \%)$ & $1(1.6 \%)$ & $2(5.0 \%)$ & $3(6.04 \%)$ \\
\hline & & 25,773 & 86,071 & 19,914 & 97,084 & 132,929 \\
\hline \multirow{2}{*}{ Establishment others } & $0(1.8 \%)$ & $0(2.7 \%)$ & $0(1.1 \%)$ & $0(1.7 \%)$ & $0(1.3 \%)$ & $0(0.85 \%)$ \\
\hline & 35,905 & 35,637 & 18,685 & 20,455 & 22,484 & 18,692 \\
\hline \multirow{2}{*}{ Establishment overall } & $5(30.4 \%)$ & $8(36.6 \%)$ & $12(37.5 \%)$ & $11(39.8 \%)$ & $17(40.3 \%)$ & $16(41.70 \%)$ \\
\hline & 449,668 & 461,048 & 660,052 & 602,468 & 730,363 & 918,278 \\
\hline \multirow{2}{*}{ Civic Party } & & & $3(6.6 \%)$ & $4(13.7 \%)$ & $5(14.1 \%)$ & $5(9.59 \%)$ \\
\hline & & & 149,375 & 207,000 & 255,007 & 207,885 \\
\hline \multirow{2}{*}{ Democratic Party } & $9(42.9 \%)$ & $9(31.6 \%)$ & $7(25.2 \%)$ & $7(20.6 \%)$ & $4(13.7 \%)$ & $5(9.22 \%)$ \\
\hline & 634,635 & 417,873 & 445,988 & 312,692 & 247,220 & 199,876 \\
\hline \multirow{2}{*}{ Labour Party } & & $2(7.3 \%)$ & $2(5.0 \%)$ & $2(2.8 \%)$ & $3(6.2 \%)$ & $1(4.63 \%)$ \\
\hline & & 96,752 & 89,185 & 73,253 & 112,140 & 101,860 \\
\hline \multirow{2}{*}{ NWSC } & $1(2.6 \%)$ & $1(4.5 \%)$ & $1(3.3 \%)$ & $1(2.8 \%)$ & $1(2.4 \%)$ & $0(0.95 \%)$ \\
\hline & 38,627 & 59,348 & 59,033 & 42,441 & 43,799 & 20,974 \\
\hline \multirow{2}{*}{ ADPL } & $0(4.0 \%)$ & $1(4.8 \%)$ & $1(4.2 \%)$ & $1(2.8 \%)$ & $0(1.7 \%)$ & $0(1.51 \%)$ \\
\hline & 59,034 & 62,717 & 74,671 & 42,211 & 30,634 & 33,255 \\
\hline \multirow{2}{*}{ New Democrats } & & & & & $1(1.6 \%)$ & $0(1.43 \%)$ \\
\hline & & & & & 28,621 & 31,595 \\
\hline The Frontier & $3(10.0 \%)$ & $2(6.8 \%)$ & $1(6.9 \%)$ & $1(2.0 \%)$ & $3(9.7 \%)$ & $1(3.86 \%)$ \\
\hline People Power & 148,507 & 89,529 & 93,200 & 33,205 & 176,250 & 85,084 \\
\hline \multirow{2}{*}{ LSD } & & $0(1.4 \%)$ & $2(5.5 \%)$ & $3(10.1 \%)$ & $1(4.9 \%)$ & $1(3.22 \%)$ \\
\hline & & 18,235 & 97,203 & 153,390 & 87,997 & 70,935 \\
\hline \multirow{2}{*}{ Hot Pop City } & & & & & & $1(7.00 \%)$ \\
\hline & & & & & & 154,176 \\
\hline ALLinHK (Youngspiration) & & & & & & $2(3.70 \%)$ \\
\hline \multirow{2}{*}{$\begin{array}{l}\text { Determinists } \\
\text { (Leftists) }\end{array}$} & & & & & & 81,410 \\
\hline & & & & & & $3(7.86 \%)$ \\
\hline \multirow{2}{*}{ Democrats others } & $2(6.6 \%)$ & $1(4.2 \%)$ & $1(4.2 \%)$ & $0(2.5 \%)$ & $0(3.1 \%)$ & $0(2.06 \%)$ \\
\hline & 98,440 & 54,795 & 73,549 & 37,515 & 55,330 & 45,258 \\
\hline \multirow{2}{*}{ Democrats overall } & $15(66.2 \%)$ & $16(60.6 \%)$ & $18(61.9 \%)$ & $19(59.5 \%)$ & $18(57.3 \%)$ & $19(54.78 \%)$ \\
\hline & 979,199 & 799,240 & $1,096,272$ & 901,707 & $1,036,998$ & $1,206,420$ \\
\hline
\end{tabular}

Notes: DAB \& FTU started to separate in 2004; The New People's Party was formed in 2011 and counted Ip Lau Shukyee Regina before it was formed; The Civic Party was formed in 2006 and counted by their shares in the 2004 election; LSD: League of Social Democrats, was formed in 2006 and counted Leung Kowk Hung and Chan Wai Yip Albert before it was formed. The Frontier was led by Emily Lau before 2009 and the People Power was formed in 2011 (more described by other tables). 
The TFU split from the DAB and participated in the election independently. Wong Kwok Hing ran for the New Territories West geographic constituency and Wong Kwok Kin ran for the Kowloon East. All the teams of DAB (seven seats, 347,373 votes, and 22.9\%) and FTU (two seats, 86,311 votes, and 5.7\%) could gain seats in the Legislative Council in the elections of different geographical districts (see Table 3). They could represent the conservative forces and participated in the direct elections quite successfully. Priscilla Leung was the only independent and conservative force who could gain a seat in the direct election in 2008. The LP participated in four constituencies through four team lists at this time but lost all the seats in the direct election $(65,622$ votes, $4.3 \%)$. It indicated that it is likely they were no longer representative in the direct election. In order to win more seats, the establishment camp started to coordinate the elections tactically. The seats they could win through direct elections approached those of the democratic camp and from the results of the elections of some constituencies, two camps could gain even seats.

The 2012 general election. The social movement for democracy faced a crucial stage inside the democratic camp in 2010, as the political reform package provided by the government initiated a controversy inside the democratic blocs. After the Five Constituencies Resignation campaign was completed, the further fragmentation of the democratic camp has become obvious since 2011. The New Democrat was established as well and their memberships were basically coming from the DP. Emily Lau, as the Chairlady and the Leader of the Frontier, led a group of members who joined the DP.

The LSD split to form a new political group, People Power (PP), which was founded in 2011 and was led by Albert Chan and Raymond Wong. But the District Councils election in 2011 showed that they were not supported by voters. The LSD allocated 28 members for the election but they were not able to win any seat. The PP sent a total number of 62 candidates to run in the election and only one was able to win. They were too radical to win at the district level elections. Hereafter, the democrats were divided between the more radical groups and the mainstream democrats. This gave rise to unprecedented chaos in the election campaigns (Ma, 2014, p. 196).

After the political reform package was passed in 2010, the Hong Kong Legislative Council election in 2012 was for a new total of 70 seats, half of which were geographical constituencies and half functional constituencies with 35 seats each.

The 2012 election witnessed serious "open fires" among the democratic parties. Ma has argued that the protracted democratization process and the logic of the electoral system made it difficult for the pro-democratic opposition to maintain a cohesive bloc forever (Ma, 2014, p. 185). It is because the Hong Kong Government adopted a counter-party stance in governance, and China formed the most important basis for the cleavage (Ma, 2014, p. 186). Or, frankly speaking, what the governance of Hong Kong would be done without any dominating power by single political party in Hong Kong is what the Chinese Communist Central Government favours and desires. The recent development of the fragmentation of the establishment camp as well as that of the democrats reflects the communist tactics. Being as the establishment camp, the DAB was controlled and limited to expand further nowadays and NPP (New People Party) was newly fostered. So, the extra-successful arrangements and expected election results were foreseeable. Also, any injustice motions and motions that were favourable to the establishment camp passed; the political parties of the pro-government blocs need not individually to shoulder the responsibility.

The DP was as ever the flagship pro-democratic party and it was characterized as suffering the worst defeat since its creation in 1991. Seemingly over-ambitious, they had eight teams contesting in five direct election districts but only gained four seats (247,220 votes, $13.7 \%)$. In fact, the DP still maintained its support, 
which was indicated by the fact that they obtained 545,308 votes (two seats, 34.26\%) in the newly initiated District Council Functional Constituency. The CP held on to their leading democratic role by winning five seats (255,007 votes, $14.1 \%)$ in five district direct elections. However, their strategy of placing Audrey Eu and Tanya Chan second on the lists in Hong Kong Island and New Territories West, intending to gain more seats, was unsuccessful in both cases.

About the elections, the phenomenon of "vote cutting-up" by various pan-democrats was prominent in the Legislative Council election in 2012. The meaning and strategy of "vote cutting-up" are the similar source of votes being distributed by political groups of similar standpoints under the fragmentation of the democratic bloc. The DP suffered its worst defeat since 1991. The deterioration of their support was very obvious and serious, going from 634,635 (nine seats in 42.9\%) votes in 1998 to 247,220 (four seats in 13.7\%) votes in 2012. The DP overestimated their popularity and over-nominated in the New Territories (three lists in the West and two lists in the East). In contrast, the progression of the $\mathrm{CP}$ was so prominent that they could secure five seats (one seat in each constituency), but unfortunately, the overflow of votes from two constituencies (Hong Kong Island 70,475 votes, $21.31 \%$ and New Territories West 72,185 votes, $14.48 \%$ ) made the other democratic blocs lose the campaign. The $\mathrm{CP}$ was ambitious enough in two constituencies and attempted to get two seats through one list. This tactic helped the establishment camp to win by the slimmest margins (Wong Kwok-hing of the FTU got 27,336 votes, $8.27 \%$ in Hong Kong Island and Lueng Chi-cheung of the DAB got 113,828 votes, $22.83 \%$ in New Territories West). However, the performance of radical democratic blocs was remarkable, and the PP, which was a newly founded political party, and the LSD almost doubled their total number of votes. The PP received nearly $10 \%$ of the popular vote and won three seats.

But the new situation, which occurred in the 2012 election, was that there were three constituencies out of five where the establishment camps gained fewer votes but won more seats. In Hong Kong Island, they gained four seats out of seven (145,729 votes and 44.07\%); in the Kowloon East, they won three seats out of five $(126,733$ votes and $44.53 \%)$; and in the New Territories West, they won five seats out of five (197,680 votes, $39.65 \%$ ). The results of the election showed that their tactic of vote allocation was quite skilfully and successfully executed. The victory of the pan-democrats in this 2012 direct election was extremely marginal, merely 18 seats against 17 seats.

The 2016 general election. The 2016 Legislative Council election came after the rejection of the constitutional reform proposal and so the mechanism was the same as during the previous term. The Occupy Movement in 2014 showed the social unrest stirring in the fight for Hong Kong democracy. Moreover, the extraordinary social action was carried out by young people on February 8, 2016, which was known as the Fishing Ball Revolution. It escalated as a result of the crackdown on unlicensed fish ball hawkers. The protesters attacked police and set fires in the streets. Needless to say, it was the most violent action against the Communist Hong Kong Government that had ever been carried out. The effect on the elections was foreseeable, as in the New Territories East by-election on February 28, 2016, Leung Tin Kei, who was unpopular but played a central role in the unrest and against expectation, received 66,524 votes (15\% of the popular vote).

The special characteristics of the Legislative Council election in 2016 were the highest voting rate ever witnessed in Hong Kong and the strategic retention to vote that kept the voters to ballot not until the last possible minute. Such that, the polling stations should be closed at half past ten and many polling stations still had long queues at this time. The last voter voted in the middle of the night after half past two. Many voters had to wait for several hours in order to support their favoured candidates (see Table 5). 
Table 4

Comparing the Results of the Legislative Council Election 2012 and 2016

\begin{tabular}{|c|c|c|c|c|c|c|c|c|c|c|c|c|}
\hline \multirow[b]{2}{*}{ Party } & \multicolumn{2}{|c|}{ HK } & \multicolumn{2}{|c|}{$\mathrm{KE}$} & \multicolumn{2}{|c|}{ KW } & \multicolumn{2}{|c|}{ NTE } & \multicolumn{2}{|c|}{ NTW } & \multicolumn{2}{|c|}{ Total } \\
\hline & 2012 & 2016 & 2012 & 2016 & 2012 & 2016 & 2012 & 2016 & 2012 & 2016 & 2012 & 2016 \\
\hline \multirow{2}{*}{$\mathrm{CP}$} & 70,475 & 35,404 & 41,669 & 45,408 & 37,925 & 32,323 & 32,753 & 52,416 & 72,185 & 42,334 & 255,077 & 207,885 \\
\hline & $21.31 \%$ & $9.40 \%$ & $14.63 \%$ & $13.80 \%$ & $16.34 \%$ & $11.59 \%$ & $7.05 \%$ & $9.03 \%$ & $14.48 \%$ & $7.02 \%$ & $14.08 \%$ & $9.59 \%$ \\
\hline \multirow{2}{*}{ DP } & 40,558 & 42,499 & 43,764 & 50,309 & 36,029 & 26,037 & 68,185 & 39,327 & 58,694 & 41,704 & 247,220 & 199,876 \\
\hline & $12.26 \%$ & $11.29 \%$ & $15.37 \%$ & $15.29 \%$ & $15.52 \%$ & $9.34 \%$ & $14.67 \%$ & $6.77 \%$ & $11.77 \%$ & $6.91 \%$ & $13.65 \%$ & $9.22 \%$ \\
\hline \multirow{2}{*}{ ADPL } & & & & & 30,364 & 15,383 & & & & 17,872 & 30,634 & 33,255 \\
\hline & & & & & $13.20 \%$ & $5.52 \%$ & & & & $2.96 \%$ & $1.69 \%$ & $1.53 \%$ \\
\hline \multirow{2}{*}{ NWSC } & & & & & & & & & 42,799 & 20,974 & 42,799 & 20,974 \\
\hline & & & & & & & & & $8.60 \%$ & $3.48 \%$ & $8.60 \%$ & $3.48 \%$ \\
\hline \multirow{2}{*}{ LAP } & 31,523 & 19,376 & & 2,535 & & & 39,650 & 49,800 & 40,967 & 30,149 & 112,140 & 101,860 \\
\hline & $9.53 \%$ & $5.15 \%$ & & $0.77 \%$ & & & $8.53 \%$ & $8.58 \%$ & $8.22 \%$ & $5.00 \%$ & $6.19 \%$ & $4.70 \%$ \\
\hline \multirow{2}{*}{ ND } & & & & & & & 28,621 & 31,595 & & & 28,621 & 31,595 \\
\hline & & & & & & & $6.16 \%$ & $5.44 \%$ & & & $6.16 \%$ & $5.44 \%$ \\
\hline \multirow{2}{*}{ LSD } & 3,169 & & 27,253 & & & 6,811 & 48,295 & 35,595 & 9,280 & 28,529 & 87,997 & 70,935 \\
\hline & $0.96 \%$ & & $9.57 \%$ & & & $2.44 \%$ & $10.39 \%$ & $6.13 \%$ & $1.86 \%$ & $4.73 \%$ & $4.86 \%$ & $3.22 \%$ \\
\hline \multirow{2}{*}{ PP } & 18,667 & 7,276 & 36,608 & 31,815 & 38,578 & & 38,024 & 45,993 & 44,355 & & 176,250 & 85,084 \\
\hline & $5.64 \%$ & $1.93 \%$ & $12.85 \%$ & $9.67 \%$ & $16.62 \%$ & & $9.93 \%$ & $7.92 \%$ & $8.91 \%$ & & $9.73 \%$ & $3.86 \%$ \\
\hline \multirow{2}{*}{ HPC } & & 22,555 & & 33,271 & & 20,219 & & 23,635 & & 54,496 & & 154,176 \\
\hline & & $5.99 \%$ & & $10.11 \%$ & & $7.25 \%$ & & $4.07 \%$ & & $9.03 \%$ & & $7.11 \%$ \\
\hline \multirow{2}{*}{ ALLinHK } & & & & 12,854 & & 20,643 & & 37,997 & & 9,928 & & 81,422 \\
\hline & & & & $3.91 \%$ & & $7.40 \%$ & & $6.55 \%$ & & $1.65 \%$ & & $3.70 \%$ \\
\hline \multirow{2}{*}{ Self } & & & & 50,818 & & 38,183 & & & & 84,121 & & 173,122 \\
\hline & & & & $13.49 \%$ & & $13.69 \%$ & & & & $13.94 \%$ & & $7.86 \%$ \\
\hline Demo & & & & & & & & & & & 980,738 & $1,160,184$ \\
\hline Total & & & & & & & & & & & $53.34 \%$ & $52.71 \%$ \\
\hline \multirow{2}{*}{ DAB } & 70,418 & 41,152 & 47,363 & 51,516 & 47,363 & 52,541 & 87,116 & 107,545 & 113,828 & 108,863 & 366,140 & 361,617 \\
\hline & $21.29 \%$ & $10.93 \%$ & $16.65 \%$ & $15.66 \%$ & 2,041 & $18.84 \%$ & $18.74 \%$ & $18.53 \%$ & $22.83 \%$ & $18.04 \%$ & $20.22 \%$ & $16.68 \%$ \\
\hline \multirow{2}{*}{ FTU } & 27,336 & 45,926 & 40,824 & 47,318 & & & 24,458 & 26,931 & 35,239 & 49,680 & 127,857 & 169,854 \\
\hline & $8.27 \%$ & $12.20 \%$ & $14.34 \%$ & $14.38 \%$ & & & $5.26 \%$ & $4.64 \%$ & $7.07 \%$ & $8.23 \%$ & $7.06 \%$ & $7.83 \%$ \\
\hline \multirow{2}{*}{ NPP } & 30,289 & 60,760 & & & & & & 36,183 & 37,808 & 70,646 & 68,097 & 167,589 \\
\hline & $9.16 \%$ & $16.13 \%$ & & & & & & $6.23 \%$ & $7.58 \%$ & $11.71 \%$ & $3.76 \%$ & $7.73 \%$ \\
\hline \multirow{2}{*}{ LP } & 17,686 & 33,323 & & & & 13,461 & 31,016 & 20,031 & & 1,469 & 48,702 & 66,984 \\
\hline & $5.35 \%$ & $8.85 \%$ & & & & $4.83 \%$ & $6.67 \%$ & $3.45 \%$ & & $0.24 \%$ & $2.69 \%$ & $3.04 \%$ \\
\hline \multirow{2}{*}{ Pillar } & & & 38,546 & 47,527 & 34,548 & 49,745 & 23,988 & & 10,805 & 35,657 & 107,887 & 132,929 \\
\hline & & & $13.54 \%$ & $14.45 \%$ & $14.89 \%$ & $17.84 \%$ & $5.16 \%$ & & $2.17 \%$ & $5.91 \%$ & $5.87 \%$ & $6.04 \%$ \\
\hline Estab. & & & & & & & & & & & 718,683 & 885,512 \\
\hline Total & & & & & & & & & & & $39.09 \%$ & $40.21 \%$ \\
\hline
\end{tabular}

From the beginning, Benny Tai wanted to coordinate the candidate lists within 23 in order to win the maximum 23 seats in the geographical constituencies. But the conflicts among the democrats were too conspicuous, so the compromises were quite obviously impossible.

As the independent movement was developing in Hong Kong, the Electoral Affairs Commission issued its plan to require all applying candidates to sign and submit a confirmation form as part of the nomination procedure in order to declare their understanding concerning inappropriately promoting Hong Kong independence. The major democratic bloc refused to sign the new declaration saying that they would uphold the Basic Law. The action was boycotted by them and the Hong Kong Government controversially merely disqualified six targeted teams of applied candidates for their advocacy for Hong Kong independence. The 
consistence was questionable and the legalized procedure was challengeable. As a consequence, a judicial review was conducted and was waiting for judgment.

There were finally 84 lists with a total of 213 candidates that contested the 35 geographical constituencies and a total of 21 candidates that belonged to nine lists and contested the five seats in the District Council (Second) Functional Constituency. It was a new historic record and 2,202,283 votes were cast out of 3,779,085 registered voters. Of the registered electorate, $58.28 \%$ was the highest turned out rate, and it occurred in the wake of the 2014 Occupy Movement (see Table 5).

Table 5

The Votes and Voting Rates of Legislative Council Elections by Year

\begin{tabular}{lllllllllllllll}
\hline Year & \multicolumn{2}{c}{1998} & \multicolumn{3}{c}{2000} & \multicolumn{2}{c}{2004} & \multicolumn{2}{c}{2008} & \multicolumn{2}{c}{2012} & \multicolumn{2}{c}{2016} \\
Regis. & \multicolumn{2}{c}{$(2,795,371)$} & \multicolumn{2}{c}{$(3,055,378)$} & \multicolumn{2}{c}{$(3,207,227)$} & \multicolumn{2}{c}{$(3,372,007)$} & $(3,466,201)$ & \multicolumn{2}{c}{$(3,779,085)$} \\
\hline Time & Votes & $\%$ & Votes & $\%$ & Votes & $\%$ & Votes & $\%$ & Votes & $\%$ & Votes & $\%$ \\
\hline $8: 30$ & 32,929 & 1.18 & 27,932 & 0.91 & 42,542 & 1.33 & 35,013 & 1.04 & 45,678 & 1.32 & 49,420 & 1.31 \\
$9: 30$ & 100,036 & 3.58 & 92,605 & 3.03 & 129,175 & 4.03 & 103,541 & 3.07 & 135,069 & 3.90 & 140,926 & 3.73 \\
$10: 30$ & 200,432 & 7.17 & 189,039 & 6.19 & 252,212 & 7.86 & 190,864 & 5.66 & 259,431 & 7.48 & 269,046 & 7.12 \\
$11: 30$ & 311,985 & 11.16 & 293,535 & 9.61 & 390,402 & 12.17 & 297,599 & 8.83 & 393,121 & 11.34 & 417,481 & 11.05 \\
$12: 30$ & 428,475 & 15.33 & 389,674 & 12.75 & 525,602 & 16.39 & 396,669 & 11.76 & 524,634 & 15.14 & 566,640 & 14.99 \\
$13: 30$ & 520,156 & 18.61 & 472,937 & 15.48 & 649,770 & 20.26 & 486,345 & 14.42 & 641,022 & 18.49 & 713,452 & 18.88 \\
$14: 30$ & 606,303 & 21.69 & 560,381 & 18.34 & 781,341 & 24.36 & 588,735 & 17.46 & 764,697 & 22.06 & 865,476 & 22.90 \\
$15: 30$ & 707,653 & 25.32 & 645,261 & 21.12 & 904,899 & 28.21 & 682,262 & 20.23 & 882,528 & 25.46 & $1,017,884$ & 26.93 \\
$16: 30$ & 835,566 & 29.89 & 729,244 & 23.87 & $1,031,144$ & 32.15 & 793,132 & 23.52 & $1,006,756$ & 29.04 & $1,177,489$ & 31.16 \\
$17: 30$ & 957,497 & 34.25 & 811,368 & 26.56 & $1,150,393$ & 35.87 & 903,133 & 26.78 & $1,131,374$ & 32.64 & $1,334,042$ & 35.30 \\
$18: 30$ & $1,067,780$ & 38.20 & 898,599 & 29.41 & $1,272,166$ & 39.67 & $1,012,574$ & 30.03 & $1,256,225$ & 36.24 & $1,494,529$ & 39.55 \\
$19: 30$ & $1,172,134$ & 41.93 & 986,922 & 32.3 & $1,392,453$ & 43.42 & $1,123,758$ & 33.33 & $1,385,120$ & 39.96 & $1,647,843$ & 43.60 \\
$20: 30$ & $1,270,660$ & 45.46 & $1,077,173$ & 35.25 & $1,519,879$ & 47.39 & $1,236,283$ & 36.66 & $1,520,003$ & 43.85 & $1,807,380$ & 47.83 \\
$21: 30$ & $1,378,371$ & 49.31 & $1,186,872$ & 38.85 & $1,633,898$ & 50.94 & $1,363,216$ & 40.43 & $1,670,381$ & 48.19 & $1,986,544$ & 52.57 \\
$22: 30$ & $1,489,705$ & 53.29 & $1,331,080$ & 43.57 & $1,784,406$ & 55.64 & $1,524,249$ & 45.20 & $1,838,722$ & 53.05 & $2,202,283$ & 58.28 \\
\hline
\end{tabular}

Needless to say from the results of the election, the victory of the localists was remarkable. But classifying their political stances, as a matter of fact, is difficult. Nathan Law comes from the newly established political party, Demosistō, and when he was one of the Occupy Movement student leaders, he was only 21 years old. He became the youngest candidate to be elected on September 4, 2016, being the party's 23-year-old chairman and still a university student. The party's allies in the election were the Land Justice League's Eddie Chu and the Democracy Groundwork's Lau Siu-lai who ran as non-partisans. The polls before the election found that the three of them just gained a low rate of support (say 1\%), but when the date of electing approached, they suddenly acquired support popularly, which indicated that the changes were possible and they were successfully elected. They gained 173,122 votes $(7.86 \%)$ and should not be overlooked. As for the traditional democratic parties, the CP and the DP, they merely gained about 200,000 votes (both slightly less than $10 \%$ of the popular vote) each, but they each won five seats. They held on to keep their basic supporters and won the marginal seats in the formidable elections. Moreover, the mini-democratic parties were seriously challenged, and as a consequence, the parties were left with only Fernando Cheung winning one seat. Many traditional and prominent political leaders were defeated completely in the election in 2016 and the democratic blocs were further fragmented, with no one group gaining more than $10 \%$ of the votes in the direct election. 
That is to say, in the 2016 election, the emergence of many new political groups led by young activists greatly affected the political landscape. Youngspiration formed an electoral alliance under the name "ALLinHK" and participated in the election with the agenda to put forward a referendum on Hong Kong's self-determination. As a result, Yau Wai-ching, a 25-year-old young woman who advocates for self-determination for Hong Kong was elected in the Kowloon West constituency. Baggio Leung, formerly not prepared to participate in the election of the New Territories East constituency and his participation was just to replace disqualified Edward Leung. Finally, he was elected. They formed the third pro-democracy party in the legislature and the result was quite unbelievable.

Raymond Wong led the other political forces of the uprising, the Civic Passion-Proletariat Political Institute-Hong Kong Resurgence Order (Hot pop city), and ran in all five geographical constituencies. They gained 154,176 votes (7.00\%), but having been tactically unsuccessful, they merely won one seat. The LSD and PP combined together to form an electoral alliance. They had six lists in five constituencies and gained 156,019 votes (7.08\%), but only Leung Kwok-hung and Ray Chan were able to be elected. As these democratic blocs are all radicalists, the author thinks that they competed and confronted each other and came up with three seats and 310,000 votes (14.19\%). They shared similar votes by 11 lists in five constituencies unfortunately. Actually, in comparison to the elections in 2012 and 2016 (see Table 4), it is interesting to note that, led by Raymond Wong, the PP and the LSD confronted each other in 2012 and gained four seats in total. The Hot pop city fought with the PP and LSD electoral alliance again, which resulted in more votes gained and fewer seats won.

For the establishment camp, a new strategy was adopted, and obviously, DAB reduced their size themselves. They had nine teams for the election in 2012 but had only seven teams in 2016. However, they could almost keep their votes and only lost 5,000 votes. The vote gain of FTU increased by nearly 42,000. The FTU kept its four teams in geographical constituencies but only three were able to gain seats as a result.

The NPP came to be a new rising star in the 2016 election, as it absorbed a regional political group - Civil Force - and expanded its regional network. Moreover, the NPP, which had received 68,097 votes (two seats and 3.8\%) in 2012 dramatically increased its number of votes to 166,899 (three seats and 7.58\%) in 2016. They scored a victory by taking three seats in the direct elections and doubled their vote share.

The LP voiced strong criticism against the Leung Chun-ying administration but assumed as the pro-establishment camp. They joined two geographical constituency elections and supported two lists as well but they lost all of them (66,984 votes, 3.04\%) and could not gain any seat in the direct elections.

In conclusion, the communists dominated the election of the establishment camp and their core votes amounted to about $40 \%$. One key question was whether they could transfer their votes from one candidate to the other to a large extent; and we doubted how this mechanism was operationalized. The establishment camp managed to win their expected seats; this was observable. If they had maximized their possible results, they should have won 20 seats, but the results were that they gained merely 16 seats.

As a matter of fact, the effect of the Occupy Movement was obvious in that the democrats were able to gain more support. The extent could be understood by comparing the results of the District Councils (Second) Functional Constituencies elections in 2012 and in 2016 respectively. The total votes gained by the establishment camp increased by no more than 80,000 votes but the gain of the democrats increased by more than 300,000 votes (see Table 6). From this result, we could project our observation that the establishment camp was exactly countable that they had insufficient votes to win more seats as in the direct election in 2016, the maximum that they could gain should be 17. As the independent, Fong Kowk Shan, and the list of LP, 
Dominic Lee, got almost 50,000 similar votes, which caused Tang Ka Biu of the FTU to be unsuccessful in the election in the New Territories East constituency.

Table 6

The Election Results of District Councils (Second) Functional Constituencies in 2012 and 2016 Respectively

\begin{tabular}{llllll}
\hline Establishment & 2012 & 2016 & Democrats & 2012 & 2016 \\
\hline DAB & 476,875 & 568,561 & DP & 545,308 & 735,597 \\
FTU & 246,196 & 233,236 & ADPL/NWSC & 262,172 & 303,457 \\
Total & 722,081 & 801,797 & Total & 807,480 & $1,108,171$ \\
\hline
\end{tabular}

\section{Discussions and Conclusions}

Negotiations concerning Hong Kong's future happened between China and Britain when the Communist People's Republic of China had just recovered from the chaotic Cultural Revolution and had begun to open-up to reforms in 1982. Hong Kong played irreplaceable role in China's reforms during this crucial period when China was impoverished and poor enough to need help from others. Hong Kong maintained more than $60 \%$ of total Chinese foreign investment for their infrastructure and other financial and technical engagements for a long time. After 30 years of economic reconstruction in China, the reforms in China were quite successful, such that nowadays it is the economic situation in Hong Kong that depends heavily on China, even though Hong Kong still maintains some advantages.

The decolonization project of the British is still questionable nowadays, as we could not summarize its usefulness and draw conclusions about its real accomplishments. The democratization of the parliamentary system by Britain was actively controlled by China, suffering under a yoke. The implementation of the Basic Law for the people of Hong Kong that Britain could haggle over power was very limited. With respect to the constitutional arrangement concerning the democratization of the Legislative Council, it was determined that until 2004 merely half of the members of the legislature could be directly elected. Subsequently, after several political reforms initiated by the communist government, the processes of democratization were obviously no longer sustainable. China has broken its promise with respect to the implementation of genuine universal suffrage. Or tactically injustice, the so-called universal suffrage, as a matter of fact, should be done by controlled nomination and the democrats refused to accept its being implemented in the Hong Kong political system.

Direct elections to the Hong Kong Legislative Council were held eight times within 25 years. As the democratization political reforms have reached a deadlock, it is unknown whether there will be further democratization. However, especially after the proportional representation election mechanism was introduced in 1998, the political parties have become increasingly pluralized, fragmentized, and radicalized. Hong Kong's citizens have obviously witnessed very frequent bickering and partisanship among various political parties (Ma, 2014, p. 189).

The legislative councillors, in non-democratic regimes and underdeveloped democracies, vet proposed bills, question officials, and hold the administration accountable through investigations, testimonies, and probes in Hong Kong (Chan, 2013, p. 86). Along the path of implementation of this constrained democracy, more peculiar political actions occurred and ultimately support was acquired to represent the political situation as if there were no alternatives in the communist-controlled Hong Kong Special Administrative Region.

In fact, the project of decolonization by the British Hong Kong Government made democratization direct to healthy development. Based on the communist intention of dominating power, it was believed firmly that the 
British should adopt conspiracy determinism to transfer power for the people of Hong Kong. The Basic Law reflected the capacity of effectively constraining a legislative institution. As the directly elected members made up $50 \%$ of the legislature, the democrats had no hope of establishing a majority in the Legislative Council.

Recently, political and social movements have frequently been radicalized. The protracted democratization makes it difficult for democrats to maintain a cohesive bloc (Ma, 2014, p. 185) actually. To the Communist Chinese Government, it did not matter whether these movements really happened in Hong Kong, the mainland also had extremely frequent massive social unrest and the social actions and protests in China which were challenging the legitimacy of the communist ruling simultaneously. Using the state apparatus to suppress social movements is nowadays very common, such that the Chinese authorities owe many types of military and physical forces. Conflicts are nothing new in China, lamentably. There are the July 1 marches and the June 4 candlelight vigils that are held annually in Hong Kong. But the assembly protest against the national education curriculum in 2012, the occupy movement for universal suffrage in 2014, and the fish ball disturbance in 2016 occurred with more and aggressive violence. The political parties are radicalizing. The newly elected legislators, as fundamentalist, replacing the mild and traditional democrats, are many youth and the tactic actions are fantastic oddities of every description. They cannot be easily classified, sometimes radicalists, fundamentalists, localists, self-determinists, and even Zionists. More actions were unprecedented in Hong Kong. Also one falls, and the next follows.

Or actually, we may find that today's Hong Kong is hardly being understood or interpreted. We do not know with respect to the half democratized political Legislative Council, whether it is a bottle of wine that is half-empty or half-full.

\section{References}

Chan, C.-K. (2013). Structural weakness of the executive-led model: Governance and party politics of Hong Kong. In J. Y. S. Cheng (Ed.), The second chief executive of Hong Kong SAR: Evaluating the Tsang Years 2005-2012 (pp. 85-112). Hong Kong: City University Press.

Chui, W.-T. (1997). Limited democratization: The politics of strategic inclusion in Hong Kong. PhD thesis, The Chinese University of Hong Kong, Hong Kong.

Hui, D. L. H. (2014). The stalemate in political reform and the rise of contentious politics in Hong Kong. In J. Y. S. Cheng (Ed.), New trends of political participation in Hong Kong (pp. 211-240). Hong Kong: City University Press.

Kuan, H-C., Lau, S.-K., Louie, K.-S., \& Wong, T. K.-Y. (Eds.). (1998). Power transfer \& electoral politics: The first legislative election in the Hong Kong Special Administrative Region. Hong Kong: The Chinese University Press.

Kwok, R., Leung, J., \& Scott, I. (Eds.). (1992). Votes without power: The Hong Kong legislative council elections 1991. Hong Kong: Hong Kong University Press.

Lo, S. S. H. (2015). Hong Kong's indigenous democracy: Origins, evolution and contentions. Hampshire: Palgrave Macmillan.

Ma, N. (2006). Strategic coordination under proportional representation: A study at the candidate level. In H.-C. Kun and T. K.-Y. Wong (Eds.), The 2004 legislative council elections in Hong Kong. Hong Kong: Hong Kong Institute of Asia-Pacific Studies, The Chinese University of Hong Kong.

Ma, N. (2007a). Democratic development in Hong Kong: A decade of lost opportunities. In J. Y. S. Cheng (Ed.), The Hong Kong Administrative Region in its first decade (pp. 49-74). Hong Kong: City University of Hong Kong Press.

Ma, N. (2007b). Political development in Hong Kong: State, political society, and civil society. Hong Kong: Hong Kong University Press.

Ma, N. (2007c). Political parties and elections. In W. M. L. Lam, L. T. Percy, W. Wong, and I. Holliday (Eds.), Contemporary Hong Kong politics: Governance in the post-1997 era (pp. 117-134). Hong Kong: Hong Kong University Press.

Ma, N. (2014). Increased pluralization and fragmentation — Party system and electoral politics and the 2012 elections. In J. Y. S. Cheng (Ed.), New trends of political participation in Hong Kong (pp. 185-210). Hong Kong: City University Press. 
Ma, N., \& Choy, C.-K. (2003). Party competition patterns: The 1995 and 1998 campaigns compared. In M. Sing (Ed.), Hong Kong government and politics (pp. 632-662). Hong Kong: Oxford University Press.

Miners, N. (1998). The government and politics of Hong Kong (5th ed.). Hong Kong: Oxford University Press.

Ng, M. (2014). Participation in the legislative council—Changes and challenges. In J. Y. S. Cheng (Ed.), New trends of political participation in Hong Kong (pp. 105-184). Hong Kong: City University Press.

Shipp, S. (1995). Hong Kong, China: A political history of the British crown colony's transfer to Chinese rule. North Carolina: McFarland \& Company. 